Abstracta Iranicacta Iranica

Revue bibliographique pour le domaine irano-aryen

Volume 24 | 2003

Comptes rendus des publications de 2001

\title{
Regards Persans. Iran, une révolution photographique. Paris, musées, 2001, 173 p.
}

\section{Agnès Devictor}

\section{Q OpenEdition \\ 1 Journals}

Édition électronique

URL : http://journals.openedition.org/abstractairanica/35025

ISSN : 1961-960X

\section{Éditeur :}

CNRS (UMR 7528 Mondes iraniens et indiens), Éditions de l'IFRI

\section{Édition imprimée}

Date de publication : 15 mai 2003

ISSN : 0240-8910

\section{Référence électronique}

Agnès Devictor, «Regards Persans. Iran, une révolution photographique. Paris, musées, 2001, 173 p. », Abstracta Iranica [En ligne], Volume 24 | 2003, document 383, mis en ligne le 05 janvier 2010, consulté le 25 septembre 2020. URL : http://journals.openedition.org/abstractairanica/35025

Ce document a été généré automatiquement le 25 septembre 2020.

Tous droits réservés 


\section{Regards Persans. Iran, une révolution photographique. Paris, musées, 2001, $173 \mathrm{p}$.}

Agnès Devictor

1 Ce catalogue d'une exposition tenue à l'Espace Electra (20 juin-31 août 2001)rassemble les œuvres de 42 photographes iraniens, classés en trois catégories « La photographie plasticienne ou les interrogations du moi », "La photographie documentaire ou la reconstruction du puzzle social», "Le photojournalisme ou le pouls de l'histoire ». Cet ouvrage, qui s'ouvre sur une introduction du philosophe Dāryūš Šāyegān, témoigne du dynamisme de la création photographique iranienne, par delà les générations et l'exil, puisqu'il juxtapose à de jeunes talents les plus grands noms de la photographie iranienne. Cette densité et cette exhaustivité, inédites il est vrai, se déploient peut-être un peu au détriment des œuvres...

\section{INDEX}

Thèmes : 17.2. Arts du spectacle

\section{AUTEURS}

AGNÈS DEVICTOR

Paris 